\title{
Direct Coal Gasification with Simultaneous Production of Electricity in a Novel Fused Metal Anode SOFC: A Theoretical Approach
}

\author{
I.V. Yentekakis ${ }^{1 *}$, P.G. Debenedetti ${ }^{2}$, B. Costa $^{3}$, M. Konsolakis ${ }^{1}$ and V. Kiousis ${ }^{1}$ \\ ${ }^{1}$ Department of Chemical Engineering, University of Patras \\ and ICE/HT-FORTH, 25600 Patras, Greece \\ ${ }^{2}$ Department of Chemical Engineering, Princeton University, Princeton, N.J., USA \\ ${ }^{3}$ Naples 801222, Italy
}

\begin{abstract}
Coal gasification in molten metal baths is a relatively new process with important technological advantages. The economics of the process can be made even more attractive if part of the Gibbs energy change of the oxidation reaction is directly converted into electricity through the use of the concept of a solid oxide fuel cell. This combination of fuel cell and fused metal gasifier in a single reactor-cell of the type: $\mathrm{C}, \mathrm{O}_{2}$, fused metal / $\mathrm{YSZ} /$ perovskite, $\mathrm{O}_{2}$ is the distinguishing feature of the new process analyzed in this work.

A mathematical model has been developed which describes the steady-state behaviour of this novel fuel cell and discusses the effect of operating conditions upon cell performance. This theoretical approach shows that, under best-case estimates, the electrochemical cell gasifier is capable of producing very high current and power densities.
\end{abstract}

\section{Introduction}

Solid electrolyte galvanic cell applications include so far their use for (i) sensor devices [1,2], (ii) power-producing systems [3] and (iii) in heterogeneous catalysis for studying the mechanism of catalytic reactions and enhancing the catalytic properties of metal electrodes via the effect of non-faradaic electrochemical modification of catalytic activity (NEMCA) or electrochemical promotion $[4,5]$.

Yet another important application of solid electrolyte devices is their use for chemical cogeneration [6-15], i.e., the simultaneous production of electricity and useful chemicals. This mode of operation combines the concepts of a fuel cell and a chemical reactor. Electricity and useful chemicals are produced simultaneously the ratio of electric power to heat generated, as well as reactant conversion, can be conveniently controlled by varying the external resistive load [15].

A number of important industrial reactions, such as the conversion of $\mathrm{NH}_{3}$ to $\mathrm{NO}$ [6] the oxidation of $\mathrm{H}_{2} \mathrm{~S}$

*Corresp. author, e-mail: yyentek@iceht.forth.gr to $\mathrm{SO}_{2}$ [7] and of methanol to formaldehyde [8], the Andrussov process for the production of HCN [9], the oxidative dehydrogenation of ethylbenzene to styrene [10] and ethylene epoxidation [11], the partial oxidation of methane to $\mathrm{H}_{2}$ and $\mathrm{CO}[12,13]$, as well as the oxidative coupling of methane to ethylene and ethane [14], have been carried out in experimental cells.

Very recently, it has been demonstrated that SOFC devices can be also used to eliminate thermodynamic restrictions imposed on conventional catalytic reactors. Thus, the ammonia synthesis at atmospheric pressure was successful under quantitative conversion of $\mathrm{H}_{2}$ to $\mathrm{NH}_{3}$ [16].

Here, we present a realistic parametric analysis of a new concept for the industrially important coal gasification process based on the use of solid electrolyte devices which has been described in detail elsewhere [17]. This novel process allows in principle the clean, efficient cogeneration of synthesis gas $\left(\mathrm{CO}+\mathrm{H}_{2}\right)$ and electricity. The idea to feed directly a solid as fuel into a fuel cell device is based on the use of a fused metal bulk anode, instead of thin metallic catalyst-electrode film [17]. 
Coal gasification in molten metal baths is a relatively new process. Important technological advantages of this process include the formation of low-sulfur coal gas, consisting mainly of $\mathrm{CO}$ and $\mathrm{H}_{2}$, i.e., the so-called synthesis gas, continuously and with high gasification efficiency and the potential of combining gasification with steel making through the use of excess gasification heat for ore melting or scrap remelting. The economics of fused iron bath gasification can be made even more attractive if part of the Gibbs energy change of the oxidation reaction is directly converted into electricity, a property which characterize fuel cell devices $[15,17,18]$.

\section{Description of the New Process}

Figure 1 is a schematic representation of the new fused metal anode solid oxide fuel cell (FMA/SOFC). Finely divided carbon is fed to the fused iron anode. Oxygen (or air) is fed into the cell's cathodic compartment. Yttriastabilized zirconia (YSZ) has been suggested as oxygen ion conducting solid electrolyte of the cell, the cathodic side wall of which is coated with perovskite type material (e.g. $\mathrm{La}_{1-x} \mathrm{Sr}_{x} \mathrm{MnO}_{3}$ ), having high catalytic activity for the dissociation of oxygen molecules. Oxygen is ionized according to the cathodic half-reaction:

$$
1 / 2 \mathrm{O}_{2}+2 \mathrm{e}^{-} \rightarrow \mathrm{O}^{2-}
$$

which occurs at the three-phase boundary between air, perovskite and zirconia. Oxygen anions migrate across the solid electrolyte's wall.

At the molten metal-zirconia interface, the anodic half reaction occurs:

$$
\mathrm{O}^{2-} \rightarrow 2 \mathrm{e}^{-}+\underline{\mathrm{O}}
$$

where $\underline{O}$ denotes atomic oxygen dissolved into the molten metal anode (dissolved oxygen in carbon-containing liquid Fe exists only in this form [19]). An anodic electron collector (Fig. 1) is used through which the electrical circuit is closed by an external load. The net result of the

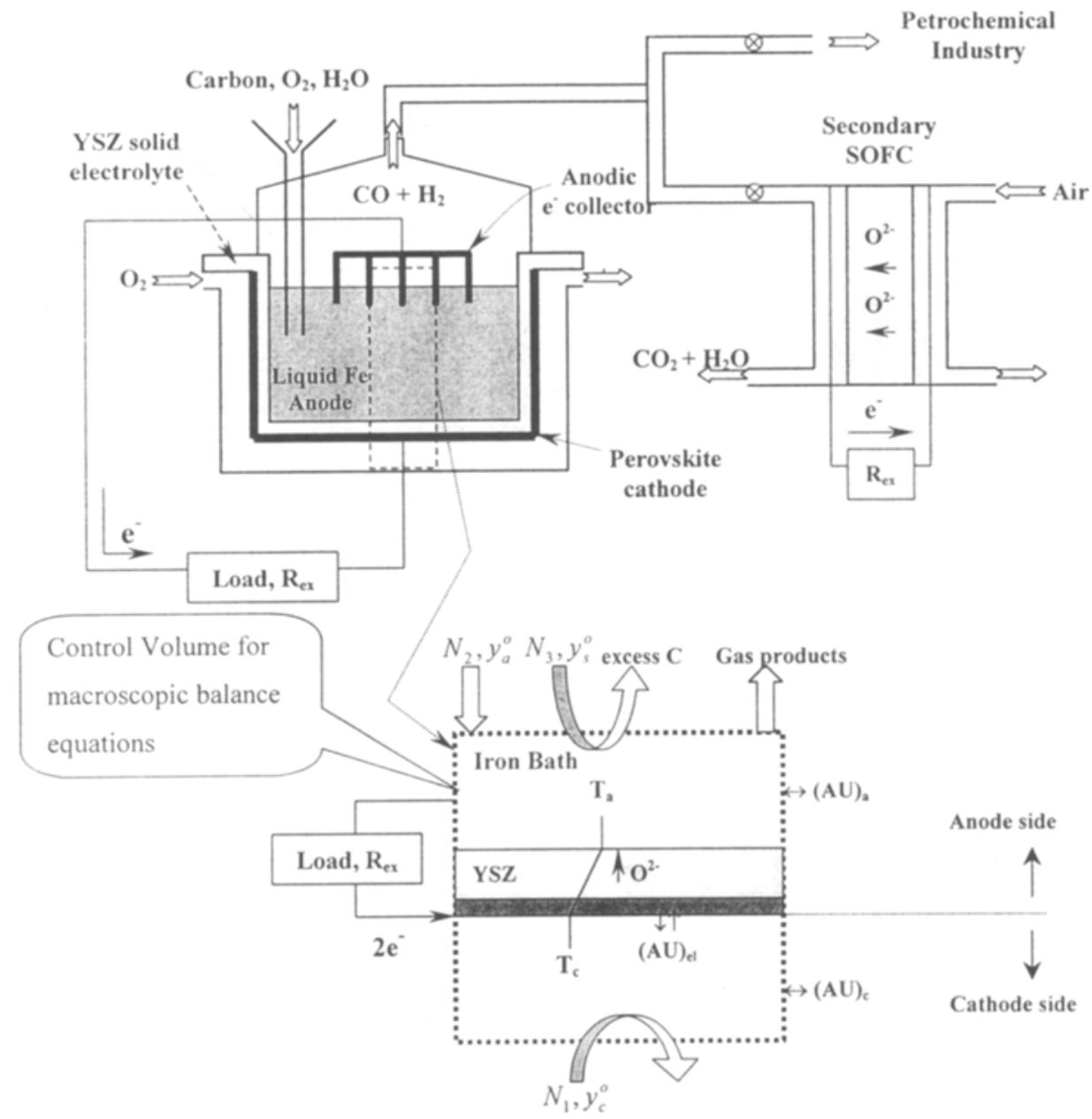

Fig. 1. Schematic representation of the Fused Metal Anode Solid Oxide Fuel Cell (FMA/SOFC) and the control volume for macroscopic balance equations. 
transport of oxygen from the cathode to anode is thus electric power.

Atomic oxygen then reacts with dissolved carbon (C) throughout the liquid anode to produce $\mathrm{CO}(\mathrm{g})$ :

$$
\underline{\mathrm{C}}(\text { in } \mathrm{Fe})+\underline{\mathrm{O}}(\text { in } \mathrm{Fe}) \rightarrow \mathrm{CO}(\mathrm{g})
$$

The overall process, therefore, allows coal to be gasified with simultaneous generation of electric power.

Oxygen can also be fed directly into the anode to provide part of the heat of reaction needed in order to sustain steady operation at high temperatures. This mode of operation implies, in principle, a compromise between a higher rate of heat generation and a lower thermodynamic driving force for the transfer of oxygen across the solid electrolyte. Our calculations, however, show a negligible effect upon the cell voltage and a significant enhancement of heat generation. A carbon monoxide rich gas stream is produced at the anode. Water vapor can also be fed at the anode if there is an interest in producing an $\mathrm{H}_{2}$-rich anodic gas stream. This case is not analyzed in the present work. The produced synthesis gas (rich in $\mathrm{CO}$ and $\mathrm{H}_{2}$ ) can be used as a feed gas to petrochemical industries or it can be fed to a subsequent SOFC for further production of electricity via the overall reactions:

$$
\begin{aligned}
& \mathrm{H}_{2}+\mathrm{O}_{2} \rightarrow \mathrm{H}_{2} \mathrm{O} \\
& \mathrm{CO}+\mathrm{O}_{2} \rightarrow \mathrm{CO}_{2}
\end{aligned}
$$

The operation of such SOFCs has been analyzed extensively in the literature [20]. As a consequence, in this work we concentrate on the analysis of the FMA/SOFC only.

\section{Model Formulation}

In order to derive the macroscopic balance equations for the FMA/SOFC reactor, we use the control volume shown schematically in Fig. 1. As a first approximation, well-mixed anodic and cathodic compartments and batch operation with respect to the molten metal bath were considered. A future extension of this work must of course include the influence of diffusional limitations, mainly in the bulk anode, by relaxing the perfect mixing assumption and introducing the cell geometry explicitly into the overall picture.

The following assumptions have been also considered when writing macroscopic balances of mass, energy and electrical equations: (i) carbon saturation at the anode and thus negligible iron oxidation [19], (ii) negligible CO production at the temperatures of interest [21], (iii) gasphase anodic oxygen is always assumed to be in equilibrium with dissolved atomic oxygen [17], and (iv) the rate determining step of the overall anodic process is the liquid phase reaction between atomic oxygen and dissolved carbon.

Operation at relatively high dissolved carbon levels is advantageous for two reasons: (i) the rate of the gasification reaction, and hence current and power density, will increase with high carbon content in the anode, (ii) the bath's melting point can be significantly lowered by the presence of dissolved carbon. In fact, the $\mathrm{Fe}-\mathrm{C}$ system offers a eutectic point at $1153{ }^{\circ} \mathrm{C}$ and 4.26 wt\% C [22], that is to say $380^{\circ} \mathrm{C}$ lower than the melting point of pure Fe.

The rate expression of the anodic liquid phase reaction can be written as [17]:

$$
\begin{gathered}
\mathrm{r}=\mathrm{k}_{\mathrm{r}}[\% \mathrm{C}]\left\{[\% \underline{\mathrm{O}}]-\mathrm{y}_{\mathrm{CO}} / \mathrm{K}_{\mathrm{e}}\right\} \phi_{1} \phi_{2}, \\
\text { where } \phi_{1}=\frac{\rho_{\mathrm{Fe}}}{1600}, \phi_{2}=\frac{\rho_{\mathrm{Fe}}}{12(100-[\% \underline{\mathrm{C}}])}
\end{gathered}
$$

Because of the novelty of the concept discussed here, there is yet no information in the literature on the kinetics of the homogeneous, liquid-phase reaction between dissolved carbon and atomic oxygen. However, an analysis [17] using $k_{r}$ as a parameter varying systematically the second-order frequency factor and activation energy over a wide range, characteristic of liquid-phase second-order reaction, showed no changes on the reactor performance indicators: the fused bath cell operates arbitrarily close to equilibrium, for any realistic choice of the pre-exponential factor and activation energy of the rate constant $k_{r}$ [17].

Based on the control volume depicted in Fig. 1, we can write the following steady-state governing equations:

- Oxygen balance for the cathode:

$$
\mathrm{N}_{1} \mathrm{y}_{\mathrm{c}}^{0} \mathbf{x}_{\mathrm{c}}=\mathrm{I} / 4 \mathrm{~F}
$$

Contrary to the usual situation encountered in hightemperature fuel cells [15], anodic oxygen feed (as considered here) introduces the need for a second oxygen material balance in order to account for electrochemical as well as direct (or chemical) oxygen conversion. Thus:

- Oxygen balance for the anode: 


$$
\left(\mathrm{N}_{1} \mathrm{y}_{\mathrm{c}}^{0} \mathrm{x}_{\mathrm{c}}+\mathrm{N}_{2} \mathrm{y}_{\mathrm{a}}^{0}\right) \mathrm{x}_{\mathrm{a}}=\mathrm{rV}_{\mathrm{a}} / 2
$$

\section{- Electrical equations:}

Assuming purely ohmic polarization, i.e., cathodic and anodic activation and concentration overpotentials were assumed to be negligible [17], we can write:

$$
E=E_{r e v}-I\left(R_{i}+R_{e l}\right)=I R_{e x}
$$

The YSZ electrolyte resistance, $R_{i}$, is an exponentially decreasing function of temperature [17]:

$$
\mathrm{R}_{\mathrm{i}}=4.17 \times 10^{-5} \exp (9700 / \mathrm{T}) \frac{\delta}{\mathrm{A}_{\mathrm{el}}}(\mathrm{Ohm})
$$

while the open-circuit voltage is given by [17]:

$$
\mathrm{E}_{\mathrm{rev}}=\frac{\mathrm{RT}}{4 \mathrm{~F}} \ln \frac{\mathrm{P}_{\mathrm{O} 2, \mathrm{c}}}{\mathrm{P}_{\mathrm{O} 2, \mathrm{a}}}
$$

where $\mathrm{P}_{\mathrm{O} 2, \mathrm{c}}$ and $\mathrm{P}_{\mathrm{O}, \mathrm{a}}$ are the partial pressures of oxygen in the well-mixed cathode and in the anodic gas product stream, respectively (the latter being in equilibrium with dissolved atomic oxygen).

$E_{\text {rev }}$ can also be computed by considering the Gibbs energy change of the reaction:

$$
\mathrm{C}(\mathrm{s})+1 / 2 \mathrm{O}_{2}(\mathrm{~g}) \rightarrow \mathrm{CO}(\mathrm{g})
$$

i.e.,

$$
2 \mathrm{FE}_{\mathrm{rev}}=-\Delta \mathrm{H}_{\mathrm{O}}+\mathrm{T}\left[\Delta \mathrm{S}_{\mathrm{O}}-\mathrm{R} \ln \frac{\alpha_{\mathrm{CO}}}{\alpha_{\mathrm{O} 2}^{1 / 2}}\right]
$$

where we have taken the activity of solid carbon to be unity and $\Delta \mathrm{H}_{\mathrm{O}}$ and $\Delta \mathrm{S}_{\mathrm{O}}$ refer to the reaction (12). The equivalence between eqs. (11) and (13) has been shown elsewhere [17].

Upon combining eqs. (9) and (11) and taking into account the mass balance equations (7) and (8). we obtain

$$
\begin{aligned}
& I\left(R_{e x}+R_{e l}+R_{i}\right) \\
& =\frac{R T}{4 F} R T \ln \frac{y_{c}^{o}\left(1-x_{c}\right)\left[\left(1+x_{a}\right)\left(a+x_{c}\right)+a b\right] P_{\mathcal{C}}}{\left(1-y_{c}^{0} x_{c}\right)\left(1-x_{a}\right)\left(a+x_{c}\right) P_{a}}
\end{aligned}
$$

where $\alpha=N_{2} y_{a}{ }^{0} / N_{1} y_{c}{ }^{0}, B=\left(1-y_{a}{ }^{0}\right) / y_{a}{ }^{0}$ and $P$ is the cathode (c) or anode (a) total pressure.

- Energy balances:

The overall energy balance for the control volume (Fig. 1 ) reads:

$$
\begin{aligned}
& \mathrm{N}_{1} \overline{\mathrm{C}}_{\mathrm{p}, \mathrm{g}}\left[\left(\mathrm{T}_{\mathrm{c}}-\mathrm{T}_{1}\right)-\left(\mathrm{T}_{\mathrm{c}}-\mathrm{T}_{\mathrm{o}}\right) \mathrm{y}_{\mathrm{c}}{ }^{0} \mathrm{x}_{\mathrm{c}}\right]+\mathrm{N}_{2} \overline{\mathrm{C}}_{\mathrm{p}, \mathrm{g}}\left\{\left(\mathrm{T}_{\mathrm{a}}-\mathrm{T}_{2}\right)+\right. \\
& \left.\left(\mathrm{T}_{\mathrm{a}}-\mathrm{T}_{\mathrm{o}}\right)\left[\mathrm{y}_{\mathrm{a}}{ }^{0} \mathrm{x}_{\mathrm{a}}+\frac{\mathrm{N}_{1}}{\mathrm{~N}_{2}} \mathrm{y}_{\mathrm{c}}{ }^{0} \mathrm{x}_{\mathrm{c}}\left(1+\mathrm{x}_{\mathrm{a}}\right)\right]\right\}+\mathrm{N}_{3} \overline{\mathrm{C}}_{\mathrm{p}, \mathrm{s}}\left\{\left(\mathrm{T}_{\mathrm{a}}-\mathrm{T}_{3}\right)-\right. \\
& \left.2 \mathrm{x}_{\mathrm{a}}\left(\mathrm{T}_{\mathrm{a}}-\mathrm{T}_{\mathrm{o}}\right)\left[\frac{\mathrm{N}_{1}}{\mathrm{~N}_{3}} \mathrm{y}_{\mathrm{c}}{ }^{0} \mathrm{x}_{\mathrm{c}}+\frac{\mathrm{N}_{2}}{\mathrm{~N}_{3}} \mathrm{y}_{\mathrm{a}}{ }^{\mathrm{o}}\right]\right\}+(\mathrm{UA})_{\mathrm{c}}\left(\mathrm{T}_{\mathrm{c}}-\mathrm{T}^{\mathrm{c}}\right)+ \\
& (\mathrm{UA})_{\mathrm{a}}\left(\mathrm{T}_{\mathrm{a}}-\mathrm{T}^{\mathrm{c}}\right)=2\left(\mathrm{~N}_{1} \mathrm{y}_{\mathrm{c}}{ }^{0} \mathrm{x}_{\mathrm{c}}+\mathrm{N}_{2} \mathrm{y}_{\mathrm{a}}{ }^{0}\right) \mathrm{x}_{\mathrm{a}}\left(-\Delta \mathrm{H}_{\mathrm{o}}\right)-\mathrm{EI}
\end{aligned}
$$

where $T_{1}, T_{2}$ and $T_{3}$ are the feed temperatures of the cathodic air, anodic air, and carbon feed streams, respectively; $T_{c}$ and $T_{a}$ are the cathode and anode temperatures, (UA) denotes the product of the overall heat transfer coefficient times the external heat-transfer area in the cathode (c) and anode (a); $\mathrm{T}^{\mathrm{c}}$ is the ambient temperature; $\mathrm{T}_{\mathrm{o}}$ is the reference temperature, and $-\Delta H_{o}$ is the standard enthalpy change, at $T_{0}$, for the reaction (12). In order to simplify the notation, we have assumed a constant molar heat capacity for all gas streams $\left(\overline{\mathrm{C}}_{\mathrm{p}, \mathrm{g}}\right) ; \overline{\mathrm{C}}_{\mathrm{p}, \mathrm{s}}$ is the heat capacity of the solid carbon. Actual calculations, of course, were performed taking into account both the temperature and the composition dependence of all heat capacities.

The right-hand side of eq. (15) is the electrochemical equivalent of the "heat generation" term encountered in conventional reactor theory. This part of eq. (15) can be written as:

$2 \mathrm{x}_{\mathrm{a}}\left(-\Delta \mathrm{H}_{\mathrm{o}}\right)\left(\mathrm{N}_{1} \mathrm{y}_{\mathrm{c}}{ }^{0} \mathrm{x}_{\mathrm{c}}+\mathrm{N}_{2} \mathrm{y}_{\mathrm{a}}{ }^{0}\right)-\mathrm{EI}=\frac{\mathrm{I}}{2 \mathrm{~F}}\left(-\Delta \mathrm{H}_{\mathrm{o}}\right)\left(\mathrm{x}_{\mathrm{a}}-\eta+\gamma\right)$

where $\eta$, commonly referred to as efficiency [18], is the ratio of actual to 'thermoneutral" voltages [20],

$$
\eta=\frac{E}{E_{\text {th }}}=\frac{E}{\left(-\Delta H_{0}\right) / 2 F}
$$

and

$$
\gamma=\mathrm{N}_{2} \mathrm{y}_{\mathrm{a}}{ }^{0} \mathrm{x}_{\mathrm{a}} /(\mathrm{I} / 4 \mathrm{~F})
$$

is the ratio of chemical to electrochemical oxygen consumption.

We need one more energy balance in order to relate $\mathrm{T}_{\mathrm{c}}$ and $\mathrm{T}_{\mathrm{a}}$. This results from considering the energy balance around the cathode:

$$
\mathrm{N}_{1} \overline{\mathrm{C}}_{\mathrm{p}, \mathrm{g}}\left(\mathrm{T}_{\mathrm{c}}-\mathrm{T}_{1}\right)+(\mathrm{UA})_{\mathrm{el}}\left(\mathrm{T}_{\mathrm{c}}-\mathrm{T}_{\mathrm{a}}\right)+(\mathrm{UA})_{\mathrm{c}}\left(\mathrm{T}_{\mathrm{c}}-\mathrm{T}^{\mathrm{c}}\right)=0
$$

where (UA) $)_{\mathrm{el}}$ is the product of the overall cathode-anode heat-transfer coefficient times the electrolyte cross-sectional area normal to the anion flow. 


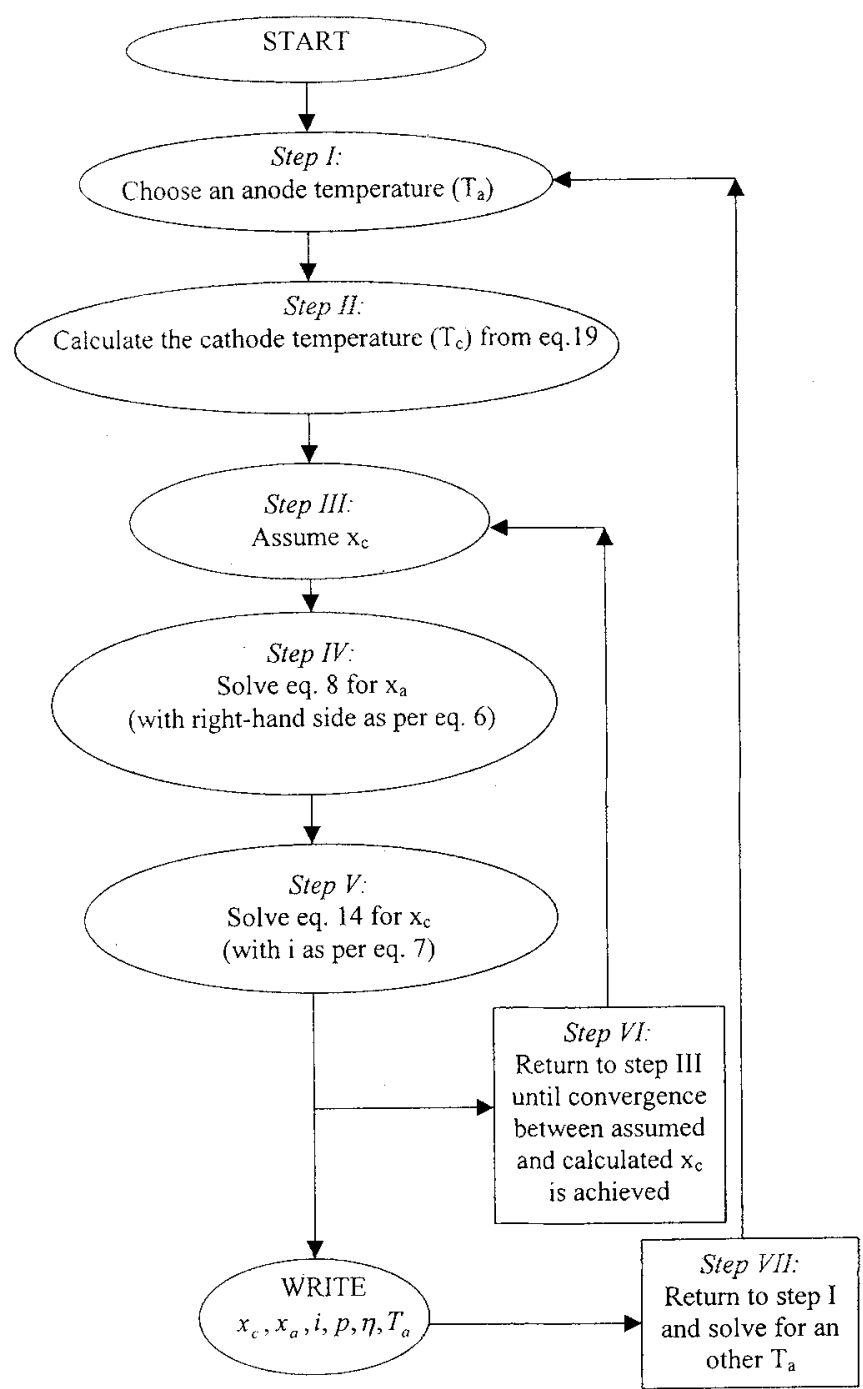

Fig. 2. Algorithm used for solving the mathematical model equations.

The governing equations of the reactor steady-state operation are therefore the two materials balances (eqs. 7 and 8), the Nernst-Kirchhoff relationship (eq. 9), the two energy balances (eqs. 12 and 16), and the rate expression (eq. 6). These were solved numerically by following the algorithm depicted in Fig. 2. Step III was solved by applying regular perturbation to the fourth-order eq. (8). Step IV (i.e., eq. 14) was solved with Newton-Raphson's method. Thus, for each imposed anode temperature, we solved the coupled kinetic-material-electrical (eqs. 6-15 and 14) iteratively. Steady-states correspond to the particular choice of anode temperature for which the energy balance is satisfied. Since the anodic temperature was chosen as an independent variable, the range of bath tem-

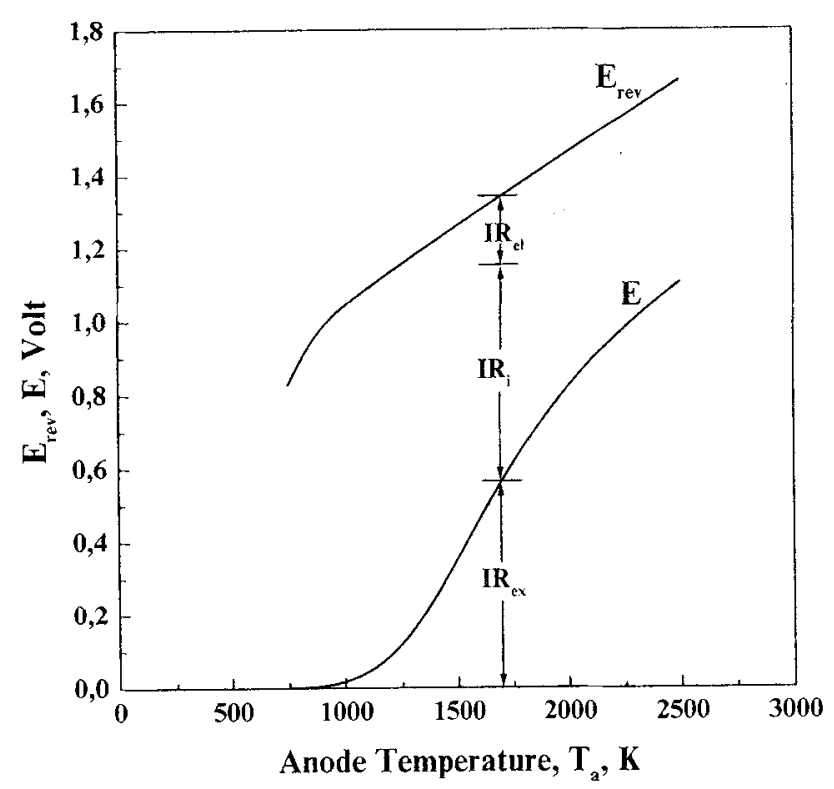

Fig. 3. Effect of anode temperature upon open-circuit and operating cell voltage. Conditions as in the nomenclature.

peratures explored includes unphysically low values, for which the anode would not exist as a liquid. Clearly, we are interested only in those steady-states for which the assumption of a fused iron bath reactor is verified.

\section{Results and Discussion}

The nomenclature in the present paper shows the values of the geometric and operating parameters used as a base case for the present calculations. The variables that were found to affect the reactor performance more significantly were anodic oxygen feed and external load. Their effects on reactor output characteristics are discussed separately below.

4.1. Behaviour of the Open-circuit and Actual Cell Voltage. Figure 3 shows the temperature dependence of the reversible (open-circuit) and actual cell voltage for the base conditions illustrated in the nomenclature. Ohmic resistances were the only source of polarization considered here. For given values of the electrode and electrolyte resistances, the difference between both curves is proportional to the current (eq. 9). The electrolyte thickness that is assumed in this study ( $2 \mathrm{~mm}$ ) is conservatively high. Accordingly, actual cell voltage values higher than those shown in Fig. 3 appear possible in an actual fuel cell. 


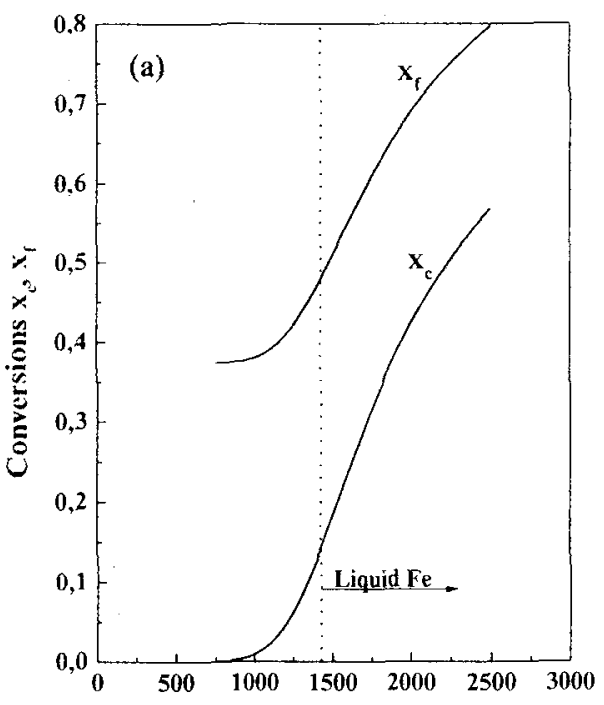

Anode Temperature, $\mathbf{T}_{\mathrm{a}}, \mathbf{K}$

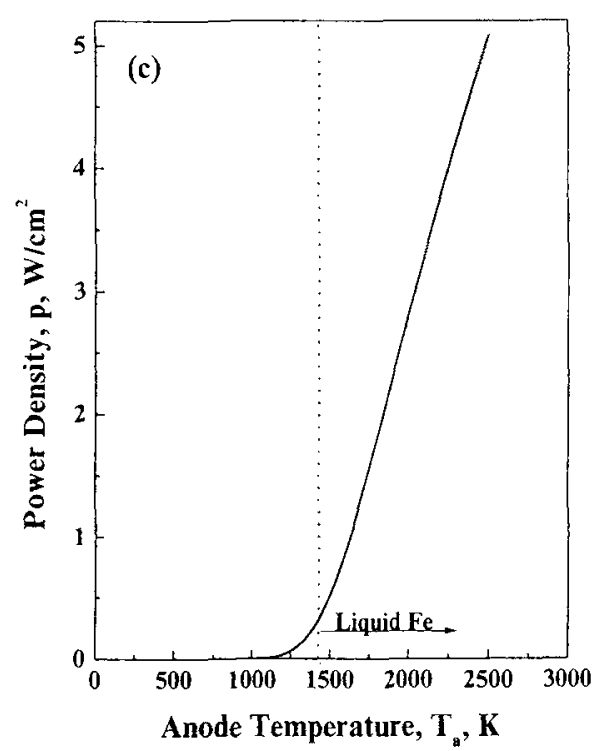

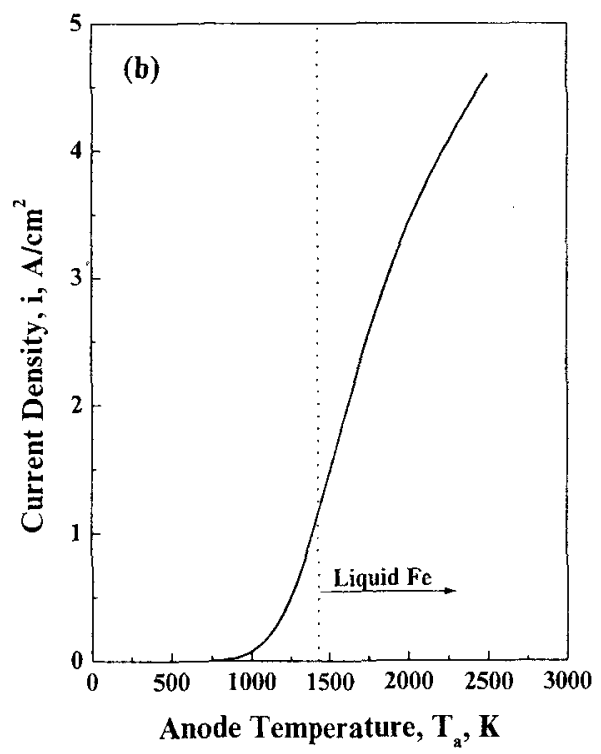

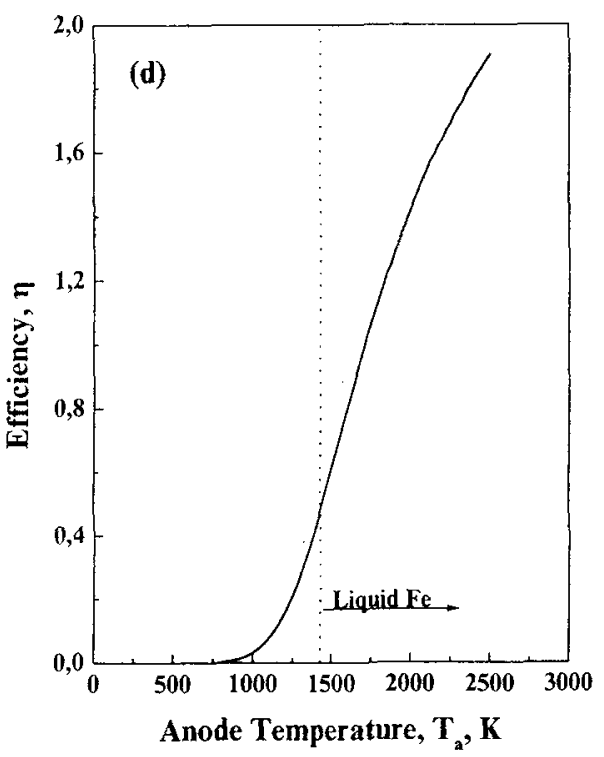

Fig. 4. Effect of anode temperature upon cathodic oxygen and carbon conversion, $x_{c}$ and $x_{f}(a)$, current density, $i$ (b), power density, $p$ (c) and efficiency, $\eta$ (d). Conditions as in Fig. 3.

Since $\Delta S_{0}$ is positive in our case, it is obvious from eq. (8) that $E_{\text {rev }}$ will, in principle, increase with temperature. At very high oxygen conversions, however. the logarithmic term in eq. (8) becomes important and $E_{\mathrm{rev}}$ can exhibit a maximum [17].

4.2. Current and Power Generation. Eq. (9) can also be written as:

$$
\mathrm{I}=\mathrm{E}_{\mathrm{rev}} /\left(\mathrm{R}_{\mathrm{ex}}+\mathrm{R}_{\mathrm{el}}+\mathrm{R}_{\mathrm{i}}\right)
$$

Since $R_{i}$ is a strongly decreasing function of temperature (eq. 10), the sign of $\mathrm{dI} / \mathrm{dT}$, which is that of $\mathrm{d} \ln \mathrm{E}_{\mathrm{rev}} / \mathrm{dT}-\left(\mathrm{R}_{\mathrm{ex}}+\mathrm{R}_{\mathrm{el}}+\mathrm{R}_{\mathrm{i}}\right)^{-1} \mathrm{~d} \mathrm{R}_{\mathrm{i}} / \mathrm{dT}$, will, in general. be positive. Thus, cathodic oxygen conversion, $x_{c}$ (see eq. 7), power output $\left(\mathrm{I}^{2} \mathrm{R}_{\mathrm{ex}}\right)$, operating voltage $\left(\mathrm{IR}_{\mathrm{ex}}\right)$, and efficiency $\mathrm{IR}_{\mathrm{cx}} /\left(-\Delta \mathrm{H}_{\mathrm{o}} / 2 \mathrm{~F}\right)$ will also, in general, be monotonously increasing functions of temperature. This behaviour is depicted in Fig. 4 and is fundamentally different from the one that characterizes other fuel cell reactions, such as $C O$ oxidation $[17,23]$ in which $\Delta S_{0}<0$. In that case, it can be shown from an analysis identical with the preceding one, that conversion, current, power output, and efficiency exhibit maxima as a function of temperature [23]. This means that because the present process in- 
volves a reaction with positive entropy change, the benefits of high-temperature operation are not only kinetic (lower activation polarization and electrolyte resistance) but also thermodynamic (since $-\Delta G_{o}$ increases with temperature and consequently, in principle, will $\mathrm{E}_{\mathrm{rev}}$ ). Based on the conditions of Fig. 4, at $\mathrm{T}_{\mathrm{a}}=1700 \mathrm{~K}$ the cell produces power density of $1.33 \mathrm{~W} / \mathrm{cm}^{2}$ at current density of $2.35 \mathrm{~A} / \mathrm{cm}^{2}$ and an operating voltage of $0.57 \mathrm{~V}$ with an efficiency of 0.97 . The gasification rate is $1195 \mathrm{~mol}$ $\mathrm{CO} / \mathrm{hm}^{2}$, i.e., $27 \mathrm{~m}^{3}(\mathrm{STP}) / \mathrm{hm}^{2}$ and the cathodic, anodic oxygen and carbon feeds are $17 \mathrm{~m}^{3}(\mathrm{STP}) / \mathrm{hm}^{2}, 8.5 \mathrm{~m}^{3}$ (STP) $/ \mathrm{hm}^{2}$ and $24 \mathrm{~kg} / \mathrm{hm}^{2}$, respectively (all the specific values are per electrolyte area normal to anion flow). In the light to what has been said above regarding to polarization sources, these figures are best-case estimates, since the model assumes negligible activation and concentration polarization, certainly an idealization at these high current densities. Indeed, our calculations [17] have shown that external mass-transfer limitations for the transport of dissolved oxygen in molten $\mathrm{Fe}$ can be significant for currents higher than $\sim 3 \mathrm{~A} / \mathrm{cm}^{2}$. In the calculation that follows, we use significantly lower current densities.

The extremely high current and power densities shown in Fig. 4 illustrate the benefits that can be obtained by minimizing ohmic losses at the electrodes, as well as by neglected possible activation and concentration overpotentials. Perovskite type materials (e.g., $\mathrm{La}_{1-\mathrm{x}} \mathrm{Sr}_{\mathrm{x}} \mathrm{MnO}_{3}, 0$ $<\mathrm{x}<0.5)$ with resistivities of the order of $4 \times 10^{-3}$

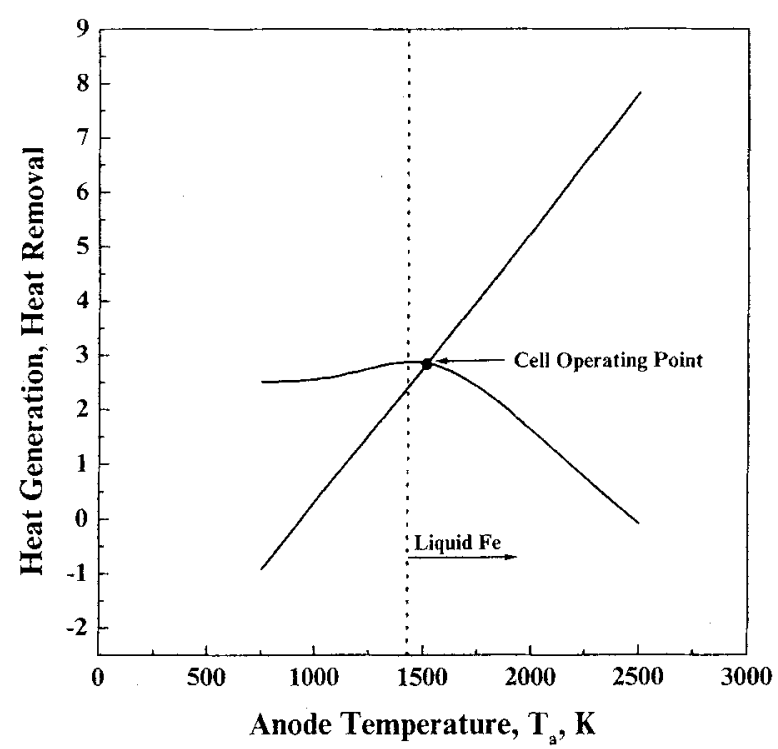

Fig. 5. Heat generation and heat removal rates (see text for discussion) as a function of anode temperature. Conditions as in Figs. 3 and 4. ohm $\mathrm{cm}$ at $1000^{\circ} \mathrm{C}[24]$ and high activity for the cathodic reaction (1) allow the attainment of very low polarization. Figure 5 illustrates the solution of the coupled material and energy balances for the same operating conditions as in Fig. 4 . The straight line is the left-hand side of eq. (15), the energy balance, and constitutes the usual heat removal term. The curve is the right-hand side of eq. (15) and is thus the electrochemical analogue of the usual heat generation function in chemical reactor engineering.

4.3. Effect of External Load $\left(R_{e x}\right)$. Figure 6 depicts the effect of the external load on cathodic oxygen conversion, $x_{c}$ (Fig. 6a), on carbon conversion, $x_{f}$ (Fig. 6b), current density, i (Fig. 6c), power density, p (Fig. 6d), efficiency, $\eta$ (Fig. 6e) and anode temperature, $T_{a}$ (Fig. 6f). It is obvious from Fig. 6a that cathodic oxygen conversion, and thus current flow, can be virtually eliminated by increasing the external resistance load. Carbon conversion, on the other hand, remains finite in this example due to the presence of direct anodic oxygen feed (Fig. $6 b)$.

It is worth noting that the cell power exhibits a maximum (Fig. 6d) with respect to $R_{e x}$ at every temperature. For purely ohmic polarization, this maximum corresponds to the condition $R_{e x}=R_{e l}+R_{i}$. This behaviour is well known for electrical circuits with ohmic elements that follow Ohm's law. By considering eq. (9) and taking into account that the power produced by the cell is $\mathrm{P}=\mathrm{IE}=$ $I^{2} R_{e x}$ we produce:

$$
\mathrm{P}=\mathrm{IE}=\mathrm{I}^{2} \mathrm{R}_{\mathrm{ex}}=\mathrm{IE}_{\mathrm{rev}}-\mathrm{I}^{2}\left(\mathrm{R}_{\mathrm{el}}+\mathrm{R}_{\mathrm{i}}\right)
$$

which is a second order equation in terms of current. The maximum power is achieved at $\mathrm{dP} / \mathrm{dI}=0$, i.e., at the current:

$$
I_{\mathrm{o}}=E_{\mathrm{rev}} / 2\left(R_{\mathrm{el}}+\mathrm{R}_{\mathrm{i}}\right)
$$

The value of the maximum power is then

$$
P_{\max }=E_{\text {rev }}^{2} / 4\left(R_{e l}+R_{i}\right)
$$

We can also express $I_{0}$ through $O h m$ 's law, i.e.,

$$
\mathrm{I}_{0}=\mathrm{E}_{\mathrm{rev}} /\left(\mathrm{R}_{\mathrm{ex}}+\mathrm{R}_{\mathrm{el}}+\mathrm{R}_{\mathrm{i}}\right)
$$

Combination of eqs. (22) and (24) provides the value of $\mathrm{R}_{\mathrm{ex}}$ at which the maximum power is obtained: 

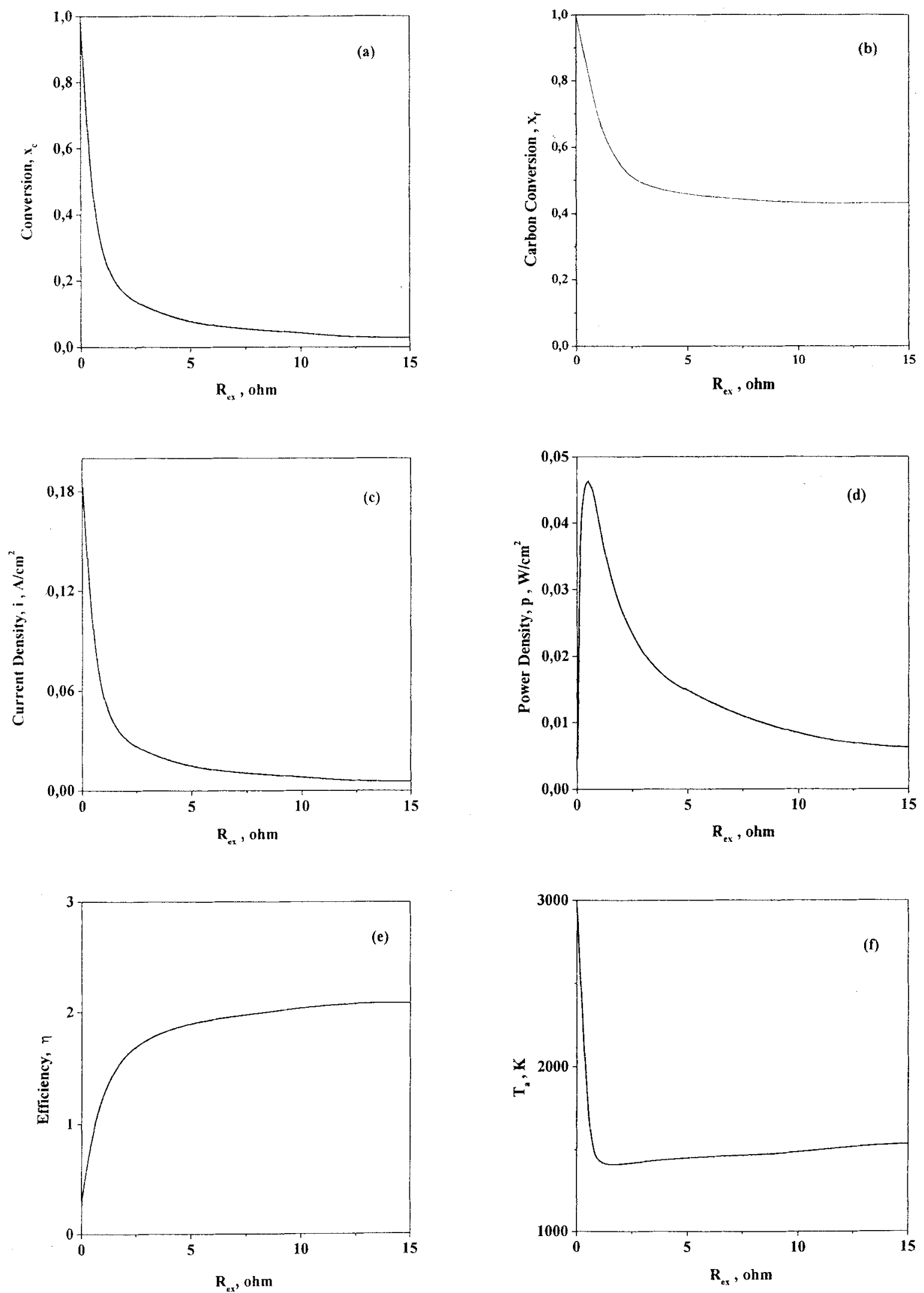

Fig. 6. Effect of the external load $\left(R_{e x}\right)$ on cathodic oxygen conversion, $x_{c}(a)$, carbon conversion, $x_{f}(b)$, current density, $i$ (c), power density, $p(d)$, efficiency, $\eta(e)$ and steady-state anodic temperature, $T_{a}(f)$. Conditions: $T_{\text {feed }}=900 \mathrm{~K}, R_{e x}=0.5$ $\mathrm{Ohm}, \mathrm{R}_{\mathrm{el}}=0.5 \mathrm{Ohm},(\mathrm{UA})_{\mathrm{c}}=1.26 \times 10^{-1} \mathrm{~J} / \mathrm{hK},(\mathrm{UA})_{\mathrm{a}}=1 \mathrm{~J} / \mathrm{hK}, \mathrm{N}_{1}=8 \times 10^{-6} \mathrm{~mol} / \mathrm{s}, \mathrm{N}_{2}=6 \times 10^{-6} \mathrm{~mol} / \mathrm{s}, \mathrm{N}_{3}=3.2 \times 10^{-5} \mathrm{~mol} / \mathrm{s}$, $y_{c}{ }^{\circ}=1, y_{a}{ }^{\circ}=1$. Other conditions as in the nomenclature. 


$$
\mathrm{R}_{\mathrm{ex}}=\mathrm{R}_{\mathrm{e} 1}+\mathrm{R}_{\mathrm{i}}
$$

Figure 7 illustrates the effect of changes in the external load upon the macroscopic energy balances and hence upon the fuel cell operating point. For any given anodic temperature and assuming $\mathrm{x}_{\mathrm{a}} \approx 1$, the heat generation is composed of three terms,

Heat Generation $=\left(-\Delta \mathrm{H}_{0}\right) \mathrm{I} / 2 \mathrm{~F}-\mathrm{I}^{2} \mathrm{R}_{\mathrm{ex}}+2 \mathrm{~N}_{2} \mathrm{y}_{\mathrm{a}}{ }^{\mathrm{o}}\left(-\Delta \mathrm{H}_{\mathrm{o}}\right)$

Since, moreover, $I \infty\left(R_{e x}+R_{e l}+R_{i}\right)^{-1}$ (see eq. 20), the heat generation is not monotonic in $R_{e x}$ : this is the behaviour shown in Fig. 7. The minimum in the anode temperature curve (Fig. 6f) is a direct consequence of the nonmonotonic behaviour of the heat generation function (Fig. 7). The monotonic decrease in $\mathrm{i}$ (and other quantities directly proportional to $i$ ) is a consequence of the fact that increasing the external load outweighs competing effects, such as the mild increase in $T_{a}$ for $R_{e x} \geq 1 \mathrm{Ohm}$. The maximum in power output with respect to $R_{e x}$ (Fig. 6d), on the other hand, follows trivially from writing $p=I^{2} R_{e x} / A_{e l}$ and monotonously decreasing behaviour of $i$ with respect to $\mathrm{R}_{\mathrm{ex}}$.

4.4. Effect of Anodic Oxygen Feed. Anodic oxygen feed can be used in the fused bath process to provide part of the heat of reaction needed to sustain steady operation at high temperature. Water vapor can be also cofed with oxygen in order to produce an anodic gas stream rich in $\mathrm{H}_{2}$. In the latter case, the ratio of $\mathrm{H}_{2} \mathrm{O} / \mathrm{O}_{2}$ must be carefully chosen,

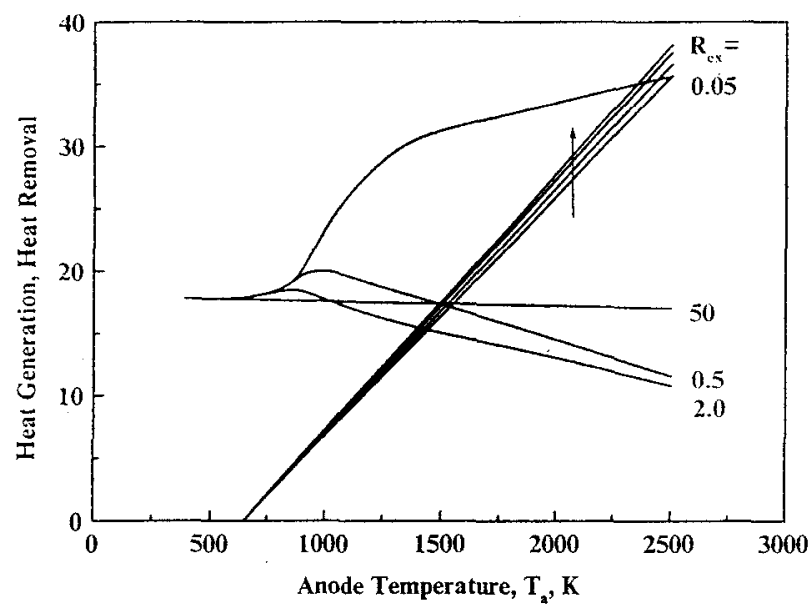

Fig. 7. Behaviour of heat generation and heat removal functions for several values of the external resistive load, $R_{e x}$. The arrow indicates the direction of increasing $R_{e x}$. Conditions as in Fig. 6. since the reaction of carbon with steam is an endothermic reaction. In the present calculations only oxygen (no water vapor) was considered to be fed in the anode gas stream with $\mathrm{N}_{2}$.

Figure 8 depicts the effect of anodic oxygen feed on the cathodic oxygen conversion, $x_{c}$ (Fig. 8a), carbon conversion, $x_{f}$ (Fig. 8b), current density, i (Fig. 8c), power density, p (Fig. 8d), efficiency, $\eta$ (Fig. 8e) and steadystate anodic temperature, $T_{a}$ (Fig. 8f). It is worth noting that the quantities $x_{c}, i$ and $\eta$ are directly proportional. We can conclude from Fig. 8 that manipulation of anodic oxygen feed allows, in principle, an extremely sensitive control of cell performance. This is obviously important from a reactor operation viewpoint.

Figure 9 illustrates the behaviour of the heat generation and heat removal function as $\mathrm{y}_{\mathrm{a}}{ }^{\circ}$ is varied (same conditions as in Fig. 8). It is obvious that the amount of oxygen fed directly into the anode has a profound influence upon the heat generation function and hence upon the reactor operating temperature.

\section{Conclusions}

The gasification of coal with simultaneous generation of electricity in a novel fused metal anode solid oxide fuel cell (FMA/SOFC) is a promising concept. The process combines the advantages of coal gasification in molten metal baths with the thermodynamic efficiency of high temperature fuel cells.

The overall reaction $\left(\mathrm{C}(\mathrm{g})+1 / 2 \mathrm{O}_{2} \rightarrow \mathrm{CO}\right)$ is accompanied furthermore by a positive entropy chance. This leads to current and power densities which, in general, tend to be monotonously increasing functions of temperature.

Operation at high temperatures necessary to maintain a molten anode is thus not only convenient from a kinetic viewpoint (negligible activation overpotential) but also for thermodynamic reasons.

Our well-mixed model shows that the reactor can produce ca. $27 \mathrm{~m}^{3}$ (STP) of $\mathrm{CO} / \mathrm{hm}^{2}$, with current and power densities of $2.4 \mathrm{~A} / \mathrm{cm}^{2}$ and $13.3 \mathrm{~kW} / \mathrm{m}^{2}$, respectively. These numbers represent best-case estimates, since the model assumes negligible activation as well as concentration polarization, certainly an idealization at these high current densities. Low ohmic losses at the electrodes are also essential for attaining of these high production rates. 

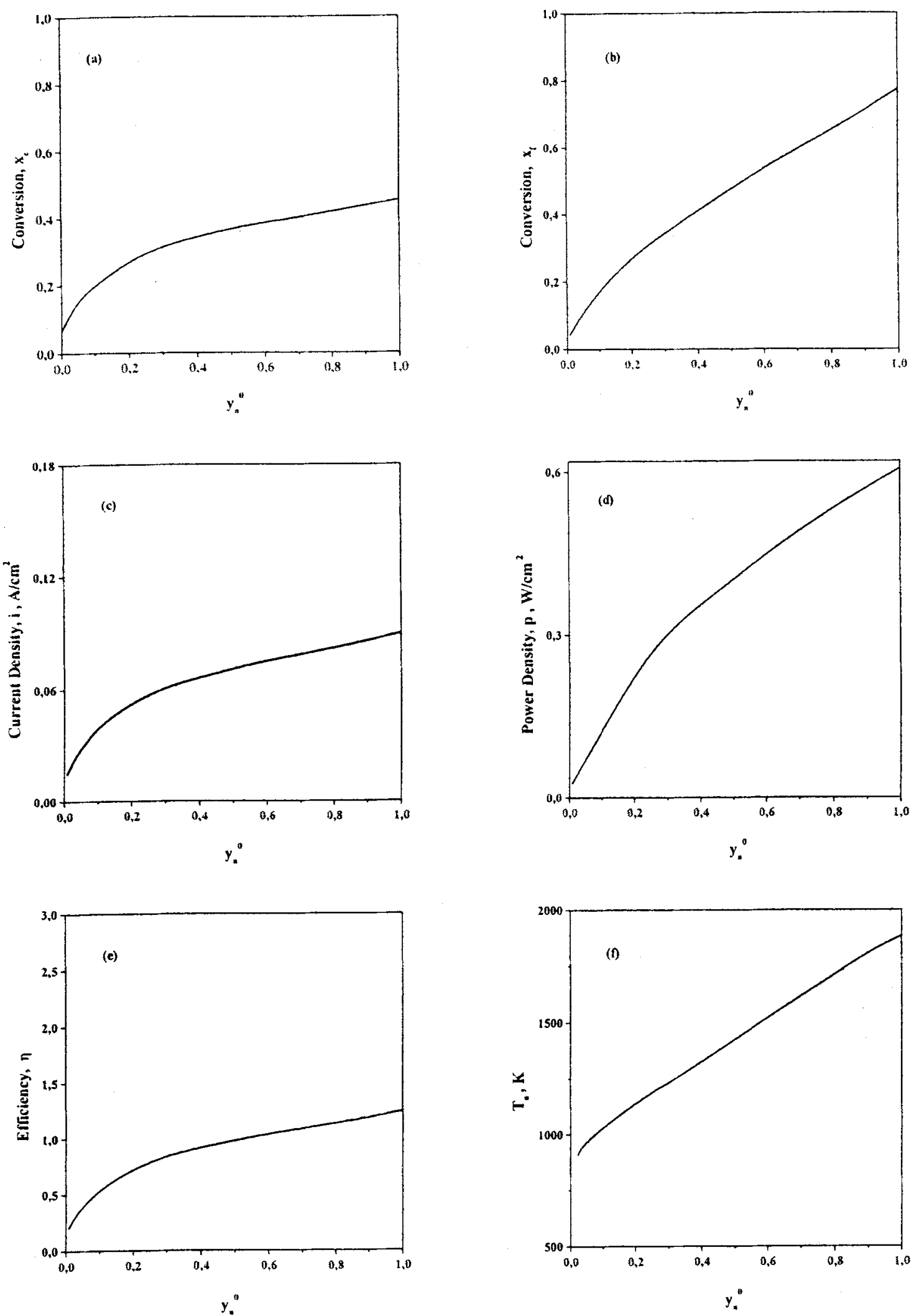

Fig. 8. Effect of anodic oxygen feed on cathodic oxygen conversion, $x_{c}(a)$, carbon conversion, $x_{f}(b)$, current density, $i$ (c), power density, $p(d)$, efficiency, $\eta(\mathrm{e})$ and anode temperature, $T_{a}(\mathrm{f})$. Conditions: $R_{e x}=0.5 \mathrm{Ohm}, \mathrm{N}_{1}=8 \times 10^{-6} \mathrm{~mol} / \mathrm{s}$, $\mathrm{N}_{2}=6 \times 10^{-6} \mathrm{~mol} / \mathrm{s}, \mathrm{R}_{\mathrm{el}}=0.5 \mathrm{Ohm}, \mathrm{N}_{3}=2.8 \times 10^{-5} \mathrm{~mol} / \mathrm{s},(\mathrm{UA})_{\mathrm{c}}=0.025 \mathrm{~J} / \mathrm{hK},(\mathrm{UA})_{\mathrm{a}}=0.2 \mathrm{~J} / \mathrm{hK}, \mathrm{y}_{\mathrm{c}}{ }^{\circ}=1, \mathrm{y}_{\mathrm{a}}{ }^{0}=1.0$ Other conditions as in the nomenclature. 


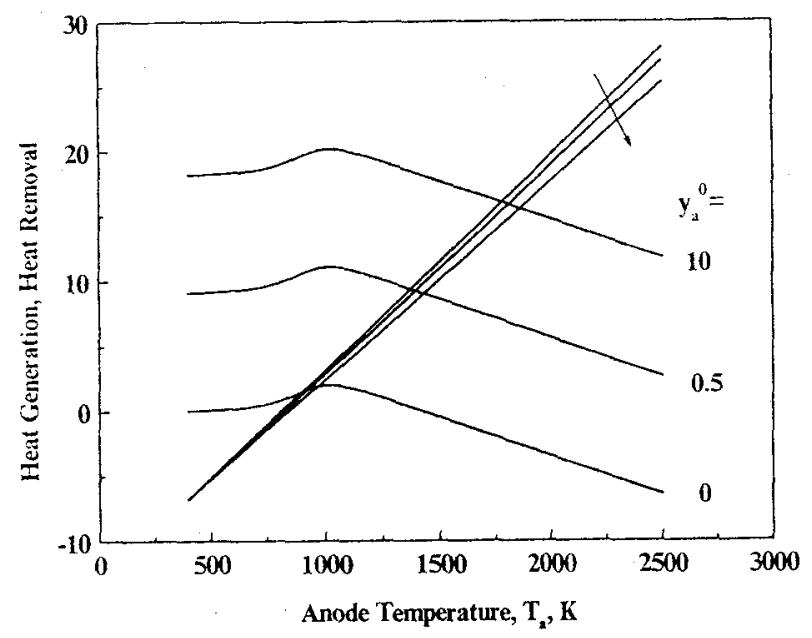

Fig. 9. Behaviour of heat generation and heat removal functions for several values of the mole fraction of oxygen in the anodic gas feed $\left(\mathrm{y}_{\mathrm{a}}^{\circ}\right)$. The arrow indicates the direction of increasing $\mathrm{y}_{\mathrm{a}}{ }^{\circ}$. Conditions as in Fig. 8.

However, it is not a restrictive factor in fuel cell technology.

Anodic oxygen feed and external load were the most important parameters found to affect crucially the reactor performance. These are easily manipulated process variables and can therefore be used to control the cell performance. External load controls the reactor's electrical power generation and anodic oxygen feed controls the reactor's operating temperature.

\section{Nomenclature}

Nomenclature and values of the geometric and operating parameters used as a base case for the present calculations:

$\mathrm{A}_{\mathrm{a}} \mathrm{A}_{\mathrm{c}}$ : anodic and cathodic heat loss area, $\mathrm{m}^{2}$

$\mathrm{A}_{\mathrm{el}}$ : superficial electrode area normal to anion flow = $1.6 \times 10^{-3} \mathrm{~m}^{2}$

$\alpha$ : ratio of anodic to cathodic oxygen flux, $\mathrm{N}_{2} \mathrm{y}_{\mathrm{a}}{ }^{0} / \mathrm{N}_{1} \mathrm{y}_{\mathrm{c}}{ }^{0}$, dimensionless

B: ratio of inert to oxygen mole fraction in anode feed, $\left.\left(1-\mathrm{y}_{\mathrm{a}}{ }^{0}\right)\right) / \mathrm{y}_{\mathrm{a}}{ }^{0}$, dimensionless

$\gamma$ : ratio of chemical to electrochemical oxygen consumption, $\mathrm{N}_{2} \mathrm{y}_{\mathrm{a}}{ }^{0} \mathrm{x}_{\mathrm{a}} /(\mathrm{I} / 4 \mathrm{~F})$

$\overline{\mathrm{C}}_{\mathrm{p}}$ : temperature - and composition - averaged specific heat, $\mathrm{J} / \mathrm{mol} \mathrm{K}$

$\overline{\mathrm{C}}_{\mathrm{p}, \mathrm{g}}^{\mathrm{o}}=31.38 \mathrm{~J} / \mathrm{mol} \mathrm{K}$, (Inlet composition, temperature average between $T_{0}$ and $T_{\text {feed }}$ )

$\overline{\mathrm{C}}_{\mathrm{p}, \mathrm{g}}=37.45 \mathrm{~J} / \mathrm{mol} \mathrm{K}$, (Outlet composition, temperature average between $T_{0}$ and $T_{a}$ )
$\overline{\mathrm{C}}_{\mathrm{p}, \mathrm{s}}^{\mathrm{o}}=15.9 \mathrm{~J} / \mathrm{mol} \mathrm{K}$, (Inlet composition, temperature average between $\mathrm{T}_{0}$ and $\left.\mathrm{T}_{\text {feed }}\right)$

$\overline{\mathrm{C}}_{\mathrm{p}, \mathrm{s}}=24.7 \mathrm{~J} / \mathrm{mol} \mathrm{K}$, (Outlet composition, temperature average between $T_{0}$ and $T_{a}$ )

$E_{r}$ : activation energy of the reaction $\underline{\mathrm{C}}+\underline{\mathrm{O}} \rightarrow \mathrm{CO}(\mathrm{g})=$ $125.4 \mathrm{~kJ} / \mathrm{mol}$

$\mathrm{E}_{\text {rev }}, \mathrm{E}$ : open-circuit and actual cell voltage, $\mathrm{V}$

$\mathrm{E}_{\mathrm{th}}$ : thermoneutral voltage, $\left(-\Delta \mathrm{H}_{\mathrm{O}}\right) / \mathrm{nF}, \mathrm{V}$

F: Faraday's constant, 96484 C/equiv.

i: current density, $\mathrm{A} / \mathrm{cm}^{2}$

$\mathrm{K}_{\mathrm{e}}$ : equilibrium constant for the reaction $\mathrm{C}$ (graphite)+ $\mathrm{Q} \rightarrow \mathrm{CO}(\mathrm{g})$, dimensionless [17].

$\mathrm{k}_{\mathrm{r}}$ : forward reaction rate constant for the reaction $\underline{\mathrm{C}}+\underline{\mathrm{O}}$ $\rightarrow \mathrm{CO}(\mathrm{g}), \mathrm{m}^{3} / \mathrm{mol} \cdot \mathrm{s}$

$\mathrm{k}_{\mathrm{r}}^{\infty}$ : preexponential factor of reaction rate constant $\mathrm{k}_{\mathrm{r}}=10^{5}$ $\mathrm{m}^{3} / \mathrm{mol} \cdot \mathrm{s}$

$\mathrm{N}_{1}$ : cathodic gas feed stream $=1.6 \times 10^{-3} \mathrm{~mol} / \mathrm{s}$

$\mathrm{N}_{2}$ : anodic gas feed stream $=8 \times 10^{-4} \mathrm{~mol} / \mathrm{s},\left(\mathrm{N}_{2}=0\right.$ whenever $y_{a}{ }^{0}=0$ )

$\mathrm{N}_{3}$ : anodic solid feed stream $=1 \times 10^{-3} \mathrm{~mol} / \mathrm{s}$

P: total pressure, $\mathrm{N} / \mathrm{m}^{2}$, or power, $\mathrm{W}$

p: power density, $\mathrm{W} / \mathrm{m}^{2}$

$\mathrm{R}_{\mathrm{el}}$ : electrode resistance $=5 \times 10^{-3} \mathrm{Ohm}$

$\mathrm{R}_{\mathrm{i}}$ : electrolyte resistance, Ohm, see eq. (10)

$\mathrm{R}_{\mathrm{cx}}$ : external resistive load $=1.5 \times 10^{-2} \mathrm{Ohm}$

$\mathrm{r}$ : reaction rate, $\mathrm{mol} / \mathrm{m}^{3} \mathrm{~s}$

$\mathrm{T}_{\mathrm{a}}$ : anode temperature, $\mathrm{K}$

$\mathrm{T}_{\mathrm{c}}$ : cathode temperature, $\mathrm{K}$

$T^{c}$ : ambient temperature $=298 \mathrm{~K}$

$\mathrm{T}_{0}:$ reference temperature $=298 \mathrm{~K}$

$\mathrm{T}_{\text {feed }}:$ stream feed temperature $=1100 \mathrm{~K}$

$\mathrm{U}$ : overall heat-transfer coefficient, $\mathrm{J} / \mathrm{s} \cdot \mathrm{m}^{2} \cdot \mathrm{K}$

$\mathrm{U}_{\mathrm{el}}=20 \mathrm{~J} / \mathrm{s} \cdot \mathrm{m}^{2} \cdot \mathrm{K}$

$(\mathrm{UA})_{\mathrm{c}}=1.26 \times 10^{-2} \mathrm{~J} / \mathrm{hK}$

$(\mathrm{UA})_{\mathrm{a}}=0.1 \mathrm{~J} / \mathrm{hK}$

$\mathrm{V}_{\mathrm{a}}$ : anodic unit cell volume $=6.4 \times 10^{-5} \mathrm{~m}^{3}$

$\mathrm{x}_{\mathrm{a}}, \mathrm{x}_{\mathrm{c}}$ : anodic and cathodic oxygen conversion, dimensionless

$\mathrm{x}_{\mathrm{f}}$ : fuel (carbon) conversion, dimensionless

$\mathrm{y}$ : mole fraction, dimensionless

$\mathrm{y}_{\mathrm{c}}{ }^{0}=0.21$

$\mathrm{y}_{\mathrm{a}}{ }^{0}=0.21$

$\mathrm{y}_{\mathrm{s}}{ }^{0}=0.9$

$\delta$ : electrolyte thickness $=2 \times 10^{-3} \mathrm{~m}$

$\rho_{\mathrm{Fe}}:$ iron density $=7.26 \times 10^{6} \mathrm{~g} / \mathrm{m}^{3}$

$\eta$ : efficiency, dimensionless

$\phi_{1}, \phi_{2}$ : coefficients defined in eq. (6), $\mathrm{mol} / \mathrm{m}^{3}$ 
$\Delta \mathrm{G}_{0}, \Delta \mathrm{H}_{\mathrm{o}}, \Delta \mathrm{S}_{\mathrm{o}}$ : Standard Gibbs energy, enthalpy and entropy change for a given reaction, $\mathrm{J} / \mathrm{mol}$

\section{References}

[1] W. Göpel, J. Hesse and J.N. Zemel, Eds., Sensors: A Comprehensive Survey, Vols. 1,2,3, VCH Publishers, Mannheim 1989, 1991.

[2] E.C. Subbarao, Solid Electrolytes and their Applications, Plenum Press. New York (1980).

[3] F. Grosz, P. Zegers, S.C. Singhal and O. Yamamoto, Eds., Proc. 2nd Int. Symposium on Solid Oxide Fuel Cells, Athens, CEC Publ, Luxembourg. 1991.

[4] C.G. Vayenas, S. Bebelis, I.V. Yentekakis and H-G. Lintz, Catalysis Today 11, 303 (1992).

[5] I.V. Yentekakis, G. Moggridge, C.G. Vayenas and R.M. Lambert, J. Catal. 146, 999 (1994).

[6] C.G. Vayenas and R.D. Farr, Science 208, 593 (1980).

[7] I.V. Yentekakis and C.G. Vayenas, J. Electrochem. Soc. 136, 996 (1984).

[8] S.G. Neophytides and C.G. Vayenas, J. Electrochem. Soc. 137, 839 (1990).

[9] N. Kiratzis and M. Stoukides, J. Electrochem. Soc. 134, 1925 (1987).

[10] J.N. Michaels and C.G. Vayenas, J. Electrochem. Soc. 131, 2544 (1984).

[11] M. Stoukides and C.G. Vayenas, ACS Symp. Ser. 178, 181 (1982).

[12] I.V. Yentekakis, Y. Jiang, S. Neophytides, S. Bebelis and C.G. Vayenas, Ionics 1, 491 (1995)

[13] V.V. Gal'vita, V.D. Belayaev, V.N. Parmon and V.A. Sobyanin, Catalysis Letters 39, 209 (1996).

[14] I.V. Yentekakis, Y. Jiang, M. Makri and C.G. Vayenas, Ionics 1, 286 (1995); Y. Jiang, I.V.
Yentekakis and C.G. Vayenas, Science 264, 1853 (1994).

[15] C.G. Vayenas, S. Bebelis, I.V. Yentekakis and S. Neophytides, in: The CRC Handbook of Solid State Electrochemistry (P.J. Gellings and H.J.M. Bouwmeester Eds.), CRC Press, New York, pp. 446-477, 1997.

[16] G. Marnelos and M. Stoukides, Science 282, 98 (1998).

[17] I.V. Yentekakis, P.G. Debenedetti and B. Costa, Ind. Eng. Chem. Res. 28, 1414 (1989); B. Costa, U.S. Patent Application 07/096,034, 1988.

[18] J. O'M. Bockris and A.K.N. Reddy, Modern Electrochemistry, Plenum Press, New York, Vol. 2, 1970.

[19] Y.K. Rao, Stoichiometry and Thermodynamics of Metallurgical Processes, Cambridge University Press, Cambridge, 1985.

[20] C.G. Vayenas, P.G. Debenedetti, I.V. Yentekakis and L.L Hegedus, Ind. Eng. Chem. Fundam. 24, 316 (1985).

[21] D.R. Gaskel. Introduction to Metallurgical Therrnodynamics. 2nd ed., McGraw-Hill. New York, 1981.

[22] J. Chipman. Met. Trans. 3, 55 (1972).

[23] P.G. Debenedetti and C.G. Vayenas, Chem. Eng. Science 38, 1817 (198J).

[24] J.T. Brown. Energy 11, 209 (1986).

Paper presented at the 6th Euroconference on Solid State Ionics, Cetraro, Calabria, Italy, Sept. 12-19, 1999.

Manuscript rev. Sept. 14, 1999; acc. Dec. 13, 1999. 